\title{
EMPATI, PERSAHABATAN, DAN KECERDASAN ADVERSITAS PADA MAHASISWA YANG SEDANG SKRIPSI
}

\author{
Nailul Fauziah \\ Fakultas Psikologi Universitas Diponegoro \\ Jl. Prof. Sudharto SH, Tembalang, Semarang, 50275 \\ nailul_f@yahoo.com
}

\begin{abstract}
The aim of this study is to investigate the correlations between empathy, friendship, and adversity intelligence on undergraduate students who were in the stage of thesis writing (skripsi). Adversity intelligence is defined as person's ability to overcome barriers and life challenges. The study sample comprised 74 undergraduate students whom, at the time of study, were in the stage of thesis writing. They were approached using a purposive random sampling. Data were collected using Empathy scale, Friendships Scale, and Adversity Intelligence Scale. The results of simple regression analysis revealed a positive and significant correlation between empathy, friendships, and adversity intelligence on subjects $\left(r_{x y}=0,165 ; p=0,001\right)$. Ability to develop empathy and to make new friends contributed to the development of students' adversity intelligence. By developing social interaction, students learn to position themselves in dealing with problems; friendships creates intimacy, support, learning from previous mistakes and new experiences to overcome barriers, particularly on these final-yearstudents.
\end{abstract}

Keywords: empathy, friendships, adversity intelligence, final-year students.

\begin{abstract}
Abstrak
Tujuan dari penelitian ini adalah untuk mengetahui hubungan antara empati, persahabatan pada kecerdasan adversitas pada mahasiswa yang sedang mengambil skripsi. Kecerdasan adversitas adalah kemampuan atau kecerdasan seseorang untuk dapat menghadapi dan tantangan hidup. Subjek penelitian adalah 74 orang mahasiswa yang sedang dalam proses mengerjakan skripsi. Sampel yang digunakan adalah purposive random sampling secaraincidental. Alat pengumpul data dalah Skala Empati, Skala Persahabatan dan Skala Kecerdasan Adversitas. Berdasarkan hasil perhitungan analisis regresi sederhana memperlihatkan nilai koefisien korelasi sebesar $r_{x y}=0,165$ dengan $p=0,001(p<0,05)$. Hasil tersebut menunjukkan adanya hubungan positif antara empati, persahabatan dan kecerdasan adversitas pada mahasiswa Psikologi Undip yang sedang mengerjakan skripsi. Kemampuan mengembangkan empati dan memiliki banyak sahabat mendukung terbentuknya kecerdaasan adversitas mahasiswa. Melalui pengembangan interaksi sosial, mahasiswa belajar untuk dapat menempatkan dirinya dalam suatu masalah, persahabatan memunculkan kehangatan, dukungan, pelajaran dari suatu kesalahan serta pengalaman baru untuk bekal menghadapi tantangan, khususnya pada mahasiswa yang sedang mengerjakan skripsi.
\end{abstract}

Kata Kunci: empati, persahabatan, kecerdasan adversitas, mahasiswa, skripsi.

\section{PENELITIAN}

Sebuah penelitian di Amerika dan Jepang menyatakan bahwa dari $100 \%$ orang sukses, hanya 10-20 persen aja yang berpendidikan tinggi, berijazah lengkap, dan tentunya dengan Intelligence Quotient (IQ) yang di atas rata-rata, selebihnya, 80-90 persen hanya lulusan SMA, SMP, atau bahkan tidak punya latar belakang pendidikan, dan kebanyakan dari mereka mengawali karir dari berdagang. Hal ini membuktikan bahwa IQ bukanlah segala-galanya. Namun ada faktor-faktor lain yang berperan dalam 
kesuksesan seseorang, antara lain oleh IQ, namun banyak kemampuan lain yang sangat berpengaruh pada kesuksesan seseorang, antara lain EQ (Emotional Quotient), SQ (Spiritual Quotient), FQ (Financial Quotient), dan AQ (Adversity Quotient).

Adversity Quotient (AQ) adalah Kemampuan / kecerdasan seseorang untuk dapat bertahan menghadapi kesulitankesulitan dan mampu mengatasi tantangan hidup. Seseorang yang memiliki kecerdasan adversitas (Adversity Intelligence) akan mampu menghadapi rintangan atau halangan yang menghadang dalam mencapai tujuan. Stoltz (2000), mengatakan bahwa sukses tidaknya seorang individu dalam pekerjaan maupun kehidupannya ditentukan oleh kecerdasan adversitas, dimana kecerdasan adversitas dapat memberitahukan: (1) seberapa jauh individu mampu bertahan menghadapi kesulitan dan kemampuan untuk mengatasinya; (2) siapa yang akan mampu mengatasi kesulitan dan siapa yang akan hancur; (3) siapa yang akan melampaui harapan harapan atas kinerja dan potensi mereka serta siapa yang akan gagal; dan (4) siapa yang akan menyerah dan siapa yang akan bertahan.

Kecerdasan adversitas mempunyai tiga bentuk. Pertama, kecerdasan adversitas adalah suatu kerangka kerja konseptual yang baru dalam memahami dan meningkatkan semua segi kesuksesan. Melalui riset-riset yang telah dilakukan kecerdasan adversitas menawarkan suatu pengetahuan baru dan praktis dalam merumuskan apa saja yang diperlukan dalam meraih keberhasilan. Kedua, kecerdasan adversitas adalah suatu ukuran untuk mengetahui respon individu terhadap kesulitan. Melalui kecerdasan adversitas pola-pola respon terhadap kesulitan tersebut untuk pertama kalinya dapat diukur, dipahami dan diubah. Ketiga, kecerdasan adversitas merupakan serangkaian peralatan yang memiliki dasar ilmiah untuk memperbaiki respon individu terhadap kesulitan yang akan mengakibatkan perbaikan efektivitas pribadi dan profesional individu secara keseluruhan (Stoltz, 2000).

Menurut Stoltz (2000), kecerdasan adversitas adalah suatu kemampuan untuk mengubah hambatan menjadi suatu peluang keberhasilan mencapai tujuan. Kecerdasan adversitas mempengaruhi pengetahuan, kreativitas, produktivitas, kinerja, usia, motivasi, pengambilan resiko, perbaikan, energi, vitalitas, stamina, kesehatan, dan kesuksesan dalam pekerjaan yang dihadapi.

Beberapa ahli lain menyebut istilah kecerdasan adversitas dengan resilience. Resilience yang berasal dari bahasa latin yaitu resilire (melompat atau mundur) adalah konsep yang berhubungan dengan adaptasi positif dalam menghadapi tantangan. Dalam ilmu perkembangan manusia, resilience memiliki makna yang luas dan beragam, mencakup kepulihan dari masa traumatis, mengatasi kegagalan dalam hidup, dan menahan stres agar dapat berfungsi dengan baik dalam mengerjakan tugas sehari-hari. Dan yg paling utama, resilience itu berarti pola adaptasi yang positif atau menunjukkan perkembangan dalam situasi sulit (Masten \& Gewirtz, 2006). Kemampuan individu untuk dapat beradaptasi dengan baik meskipun dihadapkan dengan keadaan yang sulit seringkali disebut dengan resiliensi. Menurut Papalia \& Olds (1998), resiliensi adalah sikap ulet dan tahan banting yang dimiliki seseorang ketika dihadapkan dengan keadaan yang sulit.

Berdasarkan uraian dan defenisi beberapa tokoh di atas dapat disimpulkan bahwa kecerdasan adversitas adalah kemampuan yang dimiliki individu untuk dapat mengatasi suatu kesulitan, dengan karakteristik mampu mengontrol situasi sulit, menganggap sumber-sumber kesulitan 
berasal dari luar diri, memiliki tanggung jawab dalam situasi sulit, mampu membatasi pengaruh situasi sulit dalam aspek kehidupannya, dan memiliki daya tahan yang baik dalam menghadapi situasi atau keadaan yang sulit.

Menurut Stoltz (2008), kecerdasan adversitas memiliki empat dimensi yang biasa disingkat dengan CO2RE yaitu:

a. Control (C)

Dimensi ini bertujuan untuk mengetahui seberapa banyak atau seberapa besar kontrol yang dirasakan oleh individu terhadap suatu peristiwa yang sulit. Dimensi ini mempertanyakan seberapa besar kendali yang dirasakan individu terhadap situasi yang sulit. Individu yang memiliki tingkat kecerdasan adversitas yang tinggi merasa bahwa mereka memiliki kontrol dan pengaruh yang baik pada situasi yang sulit bahkan dalam situasi yang sangat di luar kendali. Individu yang memiliki skor tinggi pada dimensi control akan berpikir bahwa pasti ada yang bisa dilakukan, selalu ada cara menghadapi kesulitan dan tidak merasa putus asa saat berada dalam situasi sulit. Individu yang memiliki kecerdasan adversitas rendah, merespon situasi sulit seolah olah mereka hanya memiliki sedikit bahkan tidak memiliki control, tidak bisa melakukan apa - apa dan biasanya mereka menyerah dalam menghadapi situasi sulit.

\section{b. Origin dan Ownership (O2)}

Dimensi ini mempertanyakan dua hal, yaitu apa atau siapa yang menjadi penyebab dari suatu kesulitan dan sampai sejauh manakah seseorang mampu menghadapi akibat - akibat yang ditimbulkan oleh situasi sulit tersebut.

\section{c. Origin}

Dimensi ini mempertanyakan siapa atau apa yang menimbulkan kesulitan. Dimensi ini berkaitan dengan rasa bersalah. Individu yang memiliki kecerdasan adversitas rendah, cenderung menempatkan rasa bersalah yang tidak semestinya atas peristiwa-peristiwa buruk yang terjadi. Dalam banyak hal, mereka melihat dirinya sendiri sebagai satusatunya penyebab atau asal usul (origin) kesulitan tersebut. Selain itu, individu yang memiliki kecerdasan adversitas rendah juga cenderung untuk menyalahkan diri sendiri. Individu yang memiliki nilai rendah pada dimensi origin cenderung berpikir bahwa ia telah melakukan kesalahan, tidak mampu, kurang memiliki pengetahuan, dan merupakan orang yang gagal. Sedangkan individu yang memiliki kecerdasan adversitas tinggi menganggap sumber-sumber kesulitan itu berasal dari orang lain atau dari luar. Individu yang memiliki tingkat origin yang lebih tinggi akan berpikir bahwa ia merasa saat ini bukan waktu yang tepat, setiap orang akan mengalami masa - masa yang sulit, atau tidak ada yang dapat menduga datangnya kesulitan.

\section{d. Ownership}

Dimensi ini mempertanyakan sejauh mana individu bersedia mengakui akibat akibat yang ditimbulkan dari situasi yang sulit. Mengakui akibat akibat yang ditimbulkan dari situasi yang sulit mencerminkan sikap tanggung jawab (ownership). Individu yang memiliki kecerdasan adversitas tinggi mampu bertanggung jawab dan menghadapi situasi sulit tanpa menghiraukan penyebabnya serta tidak akan menyalahkan orang lain. Rasa tanggung jawab yang dimiliki 
menjadikan individu yang memiliki kecerdasan adversitas tinggi untuk bertindak dan membuat mereka jauh lebih berdaya daripada individu yang memiliki kecerdasan adversitas rendah. Individu yang memiliki kecerdasan adversitas tinggi lebih unggul daripada individu yang memiliki kecerdasan adversitas rendah dalam kemampuan untuk belajar dari kesalahan. Sementara individu yang memiliki kecerdasan adversitas rendah, menolak untuk bertanggung jawab, tidak mau mengakui akibat-akibat dari suatu kesulitan dan lebih sering merasa menjadi korban serta merasa putus asa.

\section{e. $\operatorname{Reach}(R)$}

Dimensi ini merupakan bagian dari kecerdasan adversitas yang mengajukan pertanyaan sejauh mana kesulitan yang dihadapi akan mempengaruhi bagian atau sisi lain dari kehidupan individu. Individu yang memiliki kecerdasan adversitas tinggi memperhatikan kegagalan dan tantangan yang mereka alami, tidak membiarkannya mempengaruhi keadaan pekerjaan dan kehidupan mereka. Indvividu yang memiliki kecerdasan adversitas rendah membiarkan kegagalan mempengaruhi area atau sisi lain dalam kehidupan dan merusaknya.

\section{f. Endurance (E)}

Dimensi keempat ini dapat diartikan ketahanan yaitu dimensi yang mempertanyakan berapa lama suatu situasi sulit akan berlangsung. Individu yang memiliki kecerdasan adversitas rendah merasa bahwa suatu situasi yang sulit akan terjadinya selamanya. Individu yang memiliki respon yang rendah pada dimensi ini akan memandang kesulitan sebagai peristiwa yang berlangsung terus menerus dan menganggap peristiwaperistiwa positif sebagai sesuatu yang berssifat sementara. Sementara individu yang memiliki kecerdasan adversitas tinggi memiliki kemampuan yang luar biasa untuk tetap memiliki harapan dan optimis.

Stoltz (2000) menjelaskan bahwa ada beberapa faktor yang dapat mempengaruhi kecerdasan adversitas antara lain:

1) Bakat

Bakat adalah suatu kondisi pada diri seseorang yang dengan suatu latihan khusus memungkinkannya mencapai suatu kecakapan, pengetahuan dan keterampilan khusus. Bakat menggambarkan penggabungan antara keterampilan, kompetensi, pengalaman dan pengetahuan yakni apa yang diketahui dan mampu dikerjakan oleh seorang individu.

\section{2) Kemauan}

Kemauan menggambarkan motivasi, antusiasme, gairah, dorongan, ambisi, dan semangat yang menyala-nyala. Seorang individu tidak akan menjadi hebat dalam bidang apapun tanpa memiliki kemauan untuk menjadi individu yang hebat.

3) Kecerdasan

Menurut Gardner (dalam Stoltz, 2000) terdapat tujuh bentuk kecerdasan, yaitu linguistik, kinestetik, spasial, logika matematika, musik, interpersonal, dan intrapersonal. Individu memiliki semua bentuk kecerdasan sampai tahap tertentu dan beberapa di antaranya ada yang lebih dominan. Kecerdasan yang lebih dominan mempengaruhi karir yang dikejar oleh seorang individu, pelajaran-pelajaran yang dipilih, dan hobi. 
4 ) Kesehatan

Kesehatan emosi dan fisik juga mempengaruhi individu dalam mencapai kesuksesan. Jika seorang individu sakit, penyakitnya akan mengalihkan perhatian dari proses pencapaian kesuksesan. Emosi dan fisik yang sehat sangat membantu dalam pencapaian kesuksesan.

5 ) Karakteristik kepribadian

Karakteristik kepribadian seorang individu seperti kejujuran, keadilan, ketulusan hati, kebijaksanaan, kebaikan, keberanian dan kedermawanan merupakan sejumlah karakter penting dalam mencapai kesuksesan.

\section{6) Genetika}

Meskipun warisan genetis tidak menentukan nasib, namun faktor ini juga mempengaruhi kesuksesan individu. Hasil penelitian menunjukkan bahwa faktor genetik merupakan salah satu faktor yang mendasari perilaku dalam diri individu.

7) Pendidikan

Pendidikan mempengaruhi kecerdasan, pembentukan kebiasaan yang sehat, perkembangan watak, keterampilan, hasrat, dan kinerja yang dihasilkan individu.

8) Keyakinan

Keyakinan merupakan hal yang sangat penting dalam kelangsungan hidup individu. Menurut Benson (dalam Stoltz, 2000) berdoa akan mempengaruhi epinefrin dan hormone kortikosteroid pemicu stress, yang kemudian akan menurunkan tekanan darah serta membuat detak jantung dan pernafasan lebih santai. Keyakinan merupakan ciri umum yang dimiliki oleh sebagian orang- orang sukses karena iman merupakan faktor yang sangat penting dalam harapan, tindakan moralitas, kontribusi, dan bagaimana kita memperlakukan sesama kita.

Semua faktor yang telah disebutkan di atas merupakan hal-hal yang dibutuhkan untuk tetap bertahan dalam situasi yang sulit agar mencapai kesuksesan. Menurut Anthony dkk (dalam Papalia \& Olds, 1998) ada beberapa faktor yang mempengaruhi kemampuan indvidu untuk dapat berhasil beradaptasi meskipun dihadapkan pada keadaan yang sulit, yaitu kepribadian, keluarga, dan kemampuan untuk belajar dari pengalaman.

Remaja yang mampu beradaptasi dengan keadaan yang sulit adalah remaja yang adaptable. Mereka berusaha untuk melihat suatu masalah dari berbagai sisi. Mereka ramah, mandiri, dan sensitif. Mereka merasa kompeten, memiliki harga diri yang tinggi, dan cenderung menjadi siswa yang baik. Remaja yang mampu beradaptasi dengan keadaan yang sulit memiliki hubungan yang baik dengan salah satu atau kedua orangtua yang mendukungnya. Jika tidak, mereka biasanya dekat dengan orang dewasa lain yang mereka percayai. Remaja yang mampu beradaptasi dengan keadaan sulit berpengalaman dalam memecahkan masalah-masalah sosial. Mereka belajar dari orang tua, saudara yang lebih tua, atau orang lain yang berhasil mengatasi frustasi dan membuat situasi yang terbaik dari hal buruk. Mereka menghadapi perubahan yang terjadi pada diri mereka, mencari solusi, dan belajar bahwa mereka memiliki keahlian untuk mengendalikan semua hal hal buruk yang menimpa mereka.

Dacey \& Kenny (1997) juga menambahkan bahwa kemampuan remaja utk beradaptasi dengan baik meskipun dihadapkan pada situasi yang sulit dipengaruhi oleh lingkungan keluarga. Lingkungan keluarga 
yang selalu memberikan dukungan pada remaja dapat memberikan perasaan hangat pada diri remaja tersebut. Perasaan hangat merupakan salah satu faktor pelindung bagi remaja untuk menghadapi hal - hal beresiko dalam kehidupan remaja. Orang tua remaja yang dapat beradaptasi dengan keadaan sulit akan menggabungkan dukungan, pengertian dan pengawasan serta disiplin yang konsisten pada aktivitas anak-anak. Faktor kedua yang mempengaruhi kemampuan remaja untuk dapat beradaptasi dengan baik meskipun dihadapkan pada situasi sulit adalah jaringan sosial. Masyarakat yang memberikan dukungan penuh pada remaja akan membuat remaja percaya pada kemampuannya dalam mengatasi masalah. Dan faktor ketiga adalah karakteristik kepribadian.

Mahasiswa adalah peserta didik yang terdaftar dan belajar pada perguruan tinggi (Buku Pedoman Universitas Diponegoro). Mahasiswa dalam tahap perkembangannya digolongkan sebagai remaja akhir dan dewasa awal, yaitu usia 18-21 tahun dan 22-24 tahun (Monks dkk, 2001). Pada usia tersebut mahasiswa mengalami masa peralihan dari remaja akhir ke dewasa awal. Masa peralihan yang dialami oleh mahasiswa, mendorong mahasiswa untuk menghadapi berbagai tuntutan dan tugas perkembangan yang baru. Tuntutan dan tugas perkembangan mahasiswa tersebut muncul dikarenakan adanya perubahan yang terjadi pada beberapa aspek fungsional individu, yaitu fisik, psikologis dan sosial. Perubahan tersebut menuntut mahasiswa untuk melakukan penyesuaian diri.

Skripsi adalah karya ilmiah yang diwajibkan sebagai bagian dari persyaratan pendidikan akademis di Perguruan Tinggi (Poerwadarminta, 1983). Semua mahasiswa wajib mengambil mata kuliah tersebut, karena skripsi digunakan sebagai salah satu prasyarat bagi mahasiswa untuk memperoleh gelar akademisnya sebagai sarjana. Mahasiswa yang menyusun skripsi dituntut untuk dapat menyesuaikan diri dengan proses belajar yang ada dalam penyusunan skripsi.

Proses belajar yang ada dalam penyusunan skripsi berlangsung secara individual, sehingga tuntutan akan belajar mandiri sangat besar. Mahasiswa yang menyusun skripsi dituntut untuk dapat membuat suatu karya tulis dari hasil penelitian yang telah dilakukan dan diharapkan dapat bermanfaat bagi masyarakat secara umum. Peran dosen dalam pembimbingan skripsi hanya bersifat membantu mahasiswa mengatasi kesulitan yang ditemui oleh mahasiswa dalam menyusun skripsi (Redl \& Watten, 1990).

Kegagalan dalam penyusunan skripsi disebabkan oleh adanya kesulitan mahasiswa dalam mencari judul skripsi, kesulitan mencari literatur dan bahan bacaan, dana yang terbatas, serta adanya kecemasan dalam menghadapi dosen pembimbing (Riewanto, 2003). Apabila masalah-masalah tersebut menyebabkan adanya tekanan dalam diri mahasiswa maka dapat menyebabkan adanya stres dalam menyusun skripsi pada mahasiswa.

Berdasarkan pengamatan yang dilakukan oleh peneliti pada mahasiswa Program Studi Psikologi Universitas Diponegoro menunjukkan bahwa mahasiswa Program Studi Psikologi Universitas Diponegoro yang sedang menyusun skripsi juga mengalami berbagai permasalahan yang telah disebutkan di atas, seperti kecemasan menghadapi menghadapi dosen pembimbing, ditunjukkan oleh mahasiswa dalam perilaku menghindari bertemu dengan dosen pembimbing.

Berdasarkan hasil wawancara dengan beberapa mahasiswa yang sedang mengambil mata kuliah skripsi, ditemukan bahwa banyak keluhan mahasiswa mengenai sakit 
fisik ketika mengerjakan skripsi, diantaranya sakit kepala yang sering mengganggu aktivitas sehari-hari, keluhan mengenai gangguan tidur berupa kesulitan tidur, sering terlihat cemas, sering terlihat mudah marah, dan ada beberapa mahasiswa yang menunjukkan gejala gangguan daya ingat yang ditunjukkan dengan seringnya mahasiswa lupa pada janji bimbingan dengan dosen pembimbing dan janji dengan teman.

Hasil penelitian Pangestuti (2003) pada enam mahasiswa Program Studi Psikologi Fakultas Kedokteran Universitas Diponegoro menyatakan bahwa mahasiswa yang sedang menyusun skripsi dan melakukan penundaan penyelesaian skripsi mengalami peningkatan tingkat stres yang cukup tinggi. Hurlock (1991) menjelaskan ada beberapa tugas perkembangan yang mengacu pada konteks sosial yang perlu dilakukan remaja. Terdiri dari mencapai hubungan baru yang lebih matang dengan teman sebaya baik laki-laki maupun perempuan, mencapai peran sosial laki-laki dan perempuan, serta mengharapkan dan mencapai perilaku sosial yang bertanggung jawab.

Sullivan (dalam Santrock, 2003), menyatakan bahwa kebutuhan untuk kedekatan meningkat pada masa remaja awal dan hal tersebut mendorong remaja untuk mencari teman dekat dengan membangun hubungan yang akrab. Salah satu bentuk hubungan yang akrab pada remaja adalah persahabatan.

Menurut Davis (dalam Santrock, 1995), persahabatan adalah suatu bentuk hubungan dekat yang melibatkan kenikmatan, penerimaan, kepercayaan, hormat, saling menolong, menceritakan rahasia, mengerti, dan spontanitas. Sullivan (dalam Santrock, 2003) menyatakan bahwa semua orang memiliki sejumlah kebutuhan sosial dasar, termasuk kebutuhan kasih sayang, teman yang menyenangkan, penerimaan oleh lingkungan sosial, keakraban, dan hubungan seksual. Pada perkembangan kepribadian seseorang, sahabat menjadi salah satu hal yang sangat diandalkan untuk memuaskan kebutuhan-kebutuhan tersebut pada masa remaja dan segala pengalaman keberhasilan dan kegagalan dengan sahabat meningkatkan kondisi kesejahteraan para remaja. Sebaliknya, jika remaja gagal untuk membentuk persahabatan yang akrab maka akan mengalami perasaan kesepian diikuti dengan rasa harga diri yang menurun.

Persahabatan diartikan sebagai kesukarelaan, hubungan personal, secara khas mem-berikan keintiman dan bantuan, dimana dua orang tersebut menyukai satu dengan yang lainnya dan memintanya untuk menjadi teman. Ahmadi (2007), membedakan persahabatan dengan hubungan pertemanan. Persahabatan adalah suatu hubungan antar pribadi yang akrab atau intim yang melibatkan setiap individu sebagai suatu kesatuan, sedangkan hubungan pertemanan adalah hasil dari suatu hubungan formal dan suatu tingkat permulaan di dalam perkembangan suatu persahabatan.

Menurut Davis (dalam Santrock, 1995), persahabatan adalah suatu bentuk hubungan dekat yang melibatkan kenikmatan, penerimaan, kepercayaan, hormat, saling menolong, menceritakan rahasia, mengerti, dan spontanitas. Sementara itu, De Vito (1995) memaknai persahabatan sebagai hubungan interpersonal diantara dua orang yang saling menghasilkan dan memiliki karakteristik positif yang saling menghormati.

Menurut De Vries (2000) menyatakan bahwa seseorang dinilai menjadi sahabat adalah menghargai seseorang dengan kesetiaan, kepercayaan, dan mempunyai kesenangan yang sama. Berdasarkan sejumlah definisi tersebut, dapat disimpulkan bahwa persahabatan adalah 
hubungan dekat yang menghargai seseorang dengan kesetiaan, kepercayaan, dan mempunyai kesenangan yang sama.

Terdapat tiga aspek dalam persahabatan, yaitu a) friendship's affective (kasih sayang dalam persahabatan) ditandai dengan berbagi perhatian dan perasaan pribadi (seperti pengungkapan diri) dan eksplorasi yang berhubungan dengan lainnya seperti intimasi, apresiasi, dan perhatian (termasuk hormat dan perasaan kehangatan, perhatian, dan cinta). Selanjutnya, persahabatan dijelaskan sebagai pemberi dukungan, dukungan emosi, empati, dan mendukung konsep diri, dimana semuanya mungkin dibuat dengan dasar kejujuran, kesetiaan, dan komitmen; b) Shared and communal (berbagi dan berkumpul) berpartisipasi dalam kegiatan bersama, kesamaan, dan member serta menerima bantuan bukan berbentuk dukungan afektif; c) Sociability element (elemen sosial) teman merupakan sumber hiburan, kesenangan, dan rekreasi.

Menurut Davis (dalam Devito, 1995), persahabatan dapat ditentukan dari karakteristik-karakteristik berikut :

a) Kesenangan (enjoyment), seseorang menikmati saat bersama temannya

b) Penerimaan (acceptance), saling menerima satu sama lain yaitu seseorang tidak berusaha untuk mngubah temannya menjadi orang lain.

c) Saling membantu (mutual assistance), teman dapat berarti saling membantu dan mendukung.

d) Percaya (confiding), saling berbagi perasaan dan pengalaman satu sama lainnya.

e) Pengertian (understanding), seseorang dapat mengerti mengapa temannya berperilaku tertentu dan dapat memperhatikan apa yang sedang dirasakan temannya.

f) Kepercayaan (trust), saling percaya satu sama lain bahwa teman bertindak sesuatu untuk kepentingan kita yang paling baik.

g) Menghargai (respect), saling menghargai satu sama lain, berfikir teman kita membuat keputusan yang baik.

h) Spontanitas (spontaneity), seseorang dapat mengekspresikan perasaannya secara spontan tanpa khawatir bahwa ekspresi ini dapat menimbulkan kesulitan dalam persahabatan.

Ahmadi (2007) menyebutkan beberapa karakteristik pokok dari persahabatan yaitu:

a) Menghargai satu sama lain.

Menghargai satu sama lain lebih pada sebagai orang itu sendiri daripada keuntungan-keuntungan yang diperoleh dari persahabatan tersebut. Meskipun memang dari persahabatan ini diperoleh berbagai keuntungan yang bersifat sekunder, namun sebenarnya timbulnya persahabatan tersebut bersumber dan saling menyukai dan saling memelihara hubungan. Bukan kepada apakah orang tersebut menguntungkan atau tidak, sehingga dalam persahabatan bila salah satu ada unsur eksploitas, maka biasanya bubarlah persahabatan.

b) Kualitas yang objektif satu sama lain.

Menyukai seseorang karena rambutnya, uangnya, mobilnya, dan sebagainya akan membuat persahabatan akan berhenti atau terputus bila teman kehilangan apaapa yang dimilikinya. Menyukai pada hal-hal yang bersifat lahiriah semacam ini akan mudah berubah, dan lebih baik bila orang menyukai satu sama lain karena hal-hal yang terdapat pada orang itu sendiri yang sifatnya stabil.

c) Saling bertukar barang diantara teman tidak berdasar pada nilai ekonomik tetapi pada kesukaan, harapan, dan keinginan di antara mereka.

Seorang sahabat memberikan hadiah bukan dinilai dari harganya tapi pada kesukaan, harapan, dan keinginan diantara mereka.

d) Keunikannya.

Persahabatan tidak begitu saja 
diputuskan karena telah ditemukannya teman lain yang lebih baik. Persahabatan selalu mem-perlihatkan adanya keintiman, individualis, dan kesetiaan.

Berdasarkan pendapat tersebut, dapat disimpulkan bahwa karakteristik dalam persahabatan adalah kesenangan, penerimaan, saling membantu, percaya, pengertian, kepercayaan, menghargai, dan spontanitas. Persahabatan pada wanita biasanya memiliki karakteristik "emotional sharing" sedangkan persahabatan pada pria berkisar seputar melakuakn kegiatan bersama. Pada saat menjalin hubungan dengan sahabatnya, wanita lebih mendalam dari pada pria. Younnis dan Smoolar (1985), juga menyatakan hal yang sama bahwa $66 \%$ wanita dalam menjalin persahabatan yang akrab dengan intim. Sedangkan, $33 \%$ pria dalam menjalin persahabatan mempunyai karakteristik kurang pengertian, kurangnya intimasi, dan memiliki perasaan menjaga atau bertahan.

Damon (dalam Dariyo 2003), membedakan persahabatan dalam berbagai usia. Persahabatan pada early childhood (anakanak awal) usia 4-7 tahun, terjadi karena adanya perasaan kepentingan untuk bermain bersama. Pada middle childhood (anak-anak tengah) usia 8-10 tahun, persahatan sebagai upaya untuk saling membantu dan saling mempercayai santara satu dengan yang lain. Pada remaja umur 11-15 tahun, persahabatan dipandang sebagai suatu kehidupan relasi yang diwarnai dengan keakraban dan kesetiaan. Adanya pengkhianatan ataupun ketidaksetiaan diantara individu akan mengakibatkan putusnya persahabatan. Akan tetapi, apabila persahabatan ini bisa bertahan mencapai masa dewasa maka persahabatan ini akan membuat kedekatan emosional, hubungan yang semakin mendalam, dan lebih dari sekedar teman.

Sebuah penelitian yang menghubungkan kepribadian dengan peran dalam persahabatan yang dilakukan Hamment dan Peters (dalam Campbell dkk, 2002), menemukan bahwa orang yang mengalami mood yang buruk dan depresi menunjukan penolakan interpersonal oleh temantemannya dibandingkan orang-orang yang tidak mengalami depresi. Gotlib dan Whiffen (dalam Campbell dkk, 2002), juga menemukan bahwa dibandingkan dengan orang-orang yang tidak depresi, individu yang mengalami depresi melaporkan jaringan sosial yang kurang mendukung dan lebih kecil.

Kedekatan dan kesamaan merupakan faktor yang penting, karena kedekatan dapat memberi kesempatan pada orang untuk mempelajari bagaimana menghindari konflik. Kesamaan berperilaku dan karakteristik kepribadian dapat menunjang pertumbuhan dalam per-sahabatan. Melalui penjelasan tersebut dapat disimpulkan bahwa faktor-faktor yang mempengaruhi persahabatan terdiri dari jenis kelamin, usia, kepribadian, kedekatan, dan kesamaan.

Remaja menurut Buhrmester (dalam Santrock, 2003), dengan teman-teman yang tidak begitu dekat, atau tidak ada sahabat dekat sama sekali, melaporkan perasaan yang lebih sepi, lebih depresi, tegang, dan memiliki harga diri yang rendah dari pada persahabatan yang lebih akrab. Selain persahabatan, remaja juga mengembangkan keterampilan untuk dapat menjalin komunikasi dengan orang lain. Moreno (Republika, 19 Januari 2004) mengemukakan bahwa empati membantu individu mengetahui dan memahami emosi orang lain serta berbagi perasaan dengan mereka. Kemampuan untuk memahami status seseorang dalam kelompok (sosioempatis) penting bagi penyesuaian individu, karena menentukan bagaimana individu berperilaku dalam suatu situasi sosial. Empati mendorong individu untuk mengubah pola pikir yang rigid menjadi fleksibel, pola pikir yang egois menjadi toleran. 
Empati merupakan kemampuan dengan perpaduan dimensi kognitif dan afektif, dengan tidak dapat meninggalkan ranah perilaku yang menjadikan kemampuan tersebut nyata. Tanggung jawab pribadi untuk melakukan sesuatu bagi individu lain, akan berfungsi efektif bila diwujudkan dalam bentuk tingkah laku. Perpaduan dalam kemampuan empati akan membantu individu tepat dan proporsional melihat masalah yang dihadapinya.

Empati memungkinkan individu untuk memahami maksud orang lain, memprediksi perilaku mereka dan mengalami emosi yang dipicu oleh emosi mereka (Baron-Cohen \& Wheelwright, 2004). Rogers (dalam Taufik, 2012) menawarkan dua konsepsi dari empati. Pertama, melihat kerangka berpikir internal orang lain secara akurat dengan komponenkomponen yang saling berhubungan. Kedua, dalam memahami orang lain tersebut, individu seolah-olah masuk dalam diri orang lain sehingga bisa merasakan dan memahami orang lain tersebut. Empati adalah kemampuan meletakkan diri sendiri dalam posisi orang lain dan menghayati pengalaman tersebut serta untuk melihat situasi dari sudut pandang orang lain. Dengan kata lain empati merupakan kemampuan untuk menghayati perasaan dan emosi orang lain (Hurlock, 1991).

Chaplin (1997) menyebutkan bahwa empati adalah 1) memproyeksikan perasaan sendiri pada satu kejadian suatu obyek alamiah atau suatu karya estesis. 2) realisasi dan pengertian terhadap kebutuhan dan penderitaan orang lain. Menurut Hoffman (1984) empati adalah keterlibatan proses psikologis yang membuat seseorang memiliki feelings yang lebih kongruen dengan situasi diri sendiri. Berdasarkan uraian di atas dapat disimpulkan bahwa empati merupakan proses psikologis yang memungkinkan individu untuk memahami maksud orang lain, memprediksi perilaku mereka dan mengalami emosi yang dipicu oleh emosi mereka, individu seolah-olah masuk dalam diri orang lain sehingga memahami situasi dan kondisi emosional dari sudut pandang orang lain.

Memahami lebih jauh dari teori empati, tidak terlepas dari penjelasan-pernjelasan dari berbagai pendekatan. Diantaranya ada dua pendekatan yang digunakan untuk memahami teori empati, yakni teori dari Baron-Cohen \& Wheelwright (2004), yang membagi empati ke dalam dua pendekatan, yaitu pendekatan afektif dan pendekatan kognitif.

Pendekatan afektif mendefinisikan empati sebagai pengamatan emosional yang merespon afektif lain. Dalam pandangan afektif, perbedaan definisi empati dilihat dari seberapa besar dan kecilnya respon emosional pengamat pada emosi yang terjadi pada orang lain.

Terdapat empat jenis empati afektif, yaitu: 1) perasaan pada pengamat harus sesuai dengan orang yang diamati; 2) perasaan pada pengamat sesuai dengan kondisi emosional orang lain namun dengan cara yang lain; 3) pengamat merasakan emosi yang berbeda dari emosi yang dilihatnya, disebut juga sebagai empati kontras (Stotland, Sherman \& Shaver, dalam BaronCohen \& Wheelwright (2004)); 4) perasaan pada pengamat harus menjadi satu untuk perhatian atau kasih sayang pada penderitaan orang lain (Batson dalam Baron-Cohen \& Wheelwright (2004)).

Pendekatan kognitif merupakan aspek yang menimbulkan pemahaman terhadap perasaan orang lain. Eisenberg dan Strayer (dalam Baron-Cohen \& Wheelwright 2004) menyatakan bahwa salah satu yang paling mendasar pada proses empati adalah pemahaman adanya perbedaan antara individu (perceiver) dan orang lain. Dengan kata lain, adanya pemisahan antara 
perspektif sendiri, menghubungkan keadaan mental orang lain (Leslie dalam BaronCohen \& Wheelwright (2004), dan menyimpulkan kemungkinan isi dari kondisi mental mereka, serta mengingat kembali ketika hal yang sama terjadi.

Kompetensi sosial individu dalam interaksi dan keterhubungannya dengan individu lain memerlukan empati sebagai dasarnya . Membentuk hubungan yang menyenangkan, membina kedekatan hubungan serta membuat orang lain merasa nyaman bisa terbangun bila terdapat penghayatan masalah atau kebutuhan yang tersirat di balik perasaan orang lain (Goleman, 1998). Kesadaran dirilah yang mendasari empati, jika individu semakin terbuka dengan emosinya sendiri, maka ketrampilan membaca makna atas interaksi yang ada semakin meningkat (Goleman, 1998).

Berdasarkan uraian di atas, tujuan dari peneitian ini adalah Apakah ada hubungan antara persahabatan, empati terhadap kecerdasan adversitas pada mahasiswa psikologi Undip yang sedang mengambil skripsi. Hipotesis yang diajukan dalam penelitian ini adalah ada hubungan positif antara persahabatan, empati pada kecerdasan adversitas pada mahasiswa psikologi Undip yang sedang mengambil skripsi.

\section{METODE}

Populasi penelitian ini adalah mahasiswa Universitas Diponegoro yang sedang dalam tahap mengerjakan skripsi. Subjek penelitian berjumlah 74 orang mahasiswa, yang ditentukan dengan menggunakan teknik purposive sampling.

Pengambilan data menggunakan metode kuantitatif yaitu dengan menggunakan Skala Kecerdasan Adversitas, Skala Persahabatan dan Skala Empati. Skala
Kecerdasan Adversitas berjumlah 30 aitem dengan reliabilitas 0,932 . Skala kecerdasan adversitas dibuat berdasarkan dimensidimensi kecerdasan adversitas menurut Stoltz (2008), yaitu: Control (C), Origin dan Ownership (O2), Origin, Ownership, Reach $(R)$, Endurance (E).

Skala Persahabatan dibuat berdasarkan aspek-aspek persahabatan oleh De Vries, yaitu: Friendship's affective (kasih sayang dalam persahabatan), Shared and communal (berbagi dan berkumpul), dan Sociability element (elemen sosial); Jumlah aitem 24 dengan reliabilitas 0,875, sedangkan Skala Empati dibuat berdasarkan komponen empati Baron-Cohen \& Wheelwright (2004), yaitu komponen kognitif dan afektif yang terdiri dari 24 aitem dengan reliabilitas 0,943 . Metode analisis data yang akan digunakan adalah teknik analisis regresi sederhana menggunakan SPSS.

\section{HASIL DAN PEMBAHASAN}

Hasil analisis data menunjukkan adanya hubungan positif yang signifikan antara persahabatan dan empati dengan kecerdasan adversitas pada mahasiswa yang diteliti $\left(r_{x y}=0,165, p=0,001\right)$.

Nilai positif menunjukkan ada hubungan yang positif antara persahabatan, empati dan kecerdasan adversitas pada mahasiswa psikologi Undip yang sedang mengambil skripsi, dimana semakin tinggi empati dan persahabatan pada mahasiswa yang sedang mengambil skripsi, maka kecerdasan adversitas juga akan semakin tinggi, dan sebaliknya semakin rendah empati dan persahabatan pada mahasiswa yang sedang mengambil skripsi, maka kecerdasan adversitas juga akan semakin rendah.

Hal tersebut dapat dijelaskan karena definisi kecerdasan adversitas adalah kemampuan seseorang dalam menghadapi 
berbagai kesulitan di berbagai aspek kehidupannya (Stoltz, 2000). Kecerdasan Adversitas memiliki beberapa faktor yang mempengaruhi, yaitu bakat, kemauan, kecerdasan, kesehatan, karakteristik kepribadian, genetika, kemauan pribadi, pendidikan, keyakinan, keluarga dan kemampuan untuk belajar dari pengalaman.

Remaja memaknai keluarga bukan hanya orang tua, namun orang-orang yang dekat dengan mereka, termasuk sahabat. Mahasiswa yang sedang skripsi akan menemui banyak kesulitan dalam proses mereka menyelesaikan skripsinya, sangat membutuhkan dorongan atau support dari keluarganya, termasuk mereka yang dianggap keluarga, yaitu sahabat mereka (Papalia \& Olds, 1998).

Seseorang dinilai menjadi sahabat adalah menghargai seseorang dengan kesetiaan, kepercayaan, dan mempunyai kesenangan yang sama (De Vries, 2000). Adanya kejujuran (fairness) yaitu, kesediaan untuk menyingkapkan perasaan dan berbagi informasi yang bersifat pribadi baik pikiran maupun perasaan. Timbal balik (reciprocity) yaitu, lamanya waktu atau intensitas pertemanan dalam sebuah interaksi suatu hubungan. Selanjutnya, keintiman bersama (mutual intimacy) yaitu, suatu proses bersama yang melibatkan ketulusan, kehangatan, dan keakraban antara satu dengan yang lain. Aspek-aspek yang terdapat dalam persahabatan sangat relevan untuk mendukung seseorang ketika mengalami hambatan dan kesulitan dalam kehidupannya.

Kehidupan mahasiswa psikologi memiliki berbagai tuntutan tugas dan tanggung jawab yang juga mendorong mahasiswa untuk berteman, membutuhkan social support dari sahabat-sahabatnya, tuntutan tugas setiap mata kuliah mengharuskan mahasiswa bekerja sama, terutama pada saat mengerjakan skripsi. Berbagai rintangan ketika bertemu dosen, mencari referensi, hingga terjun ke lapangan untuk mencari data menjadikan mahasiswa tidak mungkin mengerjakannya sendirian. Hal tersebut mendorong mahasiswa menjalin pertemanan, persahabatan sebagai kebutuhan yang penting dalam menyelesaikan tugasnya.

Pada akhirnya hubungan timbal balik pertemanan juga akan memunculkan rasa empati pada teman dan sahabat. Pengalaman mengerjakan skripsi merupakan pengalaman yang berarti bagi mahasiswa, dapat menjadi ajang atau situasi melatih kemampuan empati mahasiswa, karena bersama-sama merasa senasib, mengerjakan tugas dan target untuk menyelesaikan studinya.

Selain hal tersebut di atas, terdapat faktor lain yang menunjukkan adanya hubungan yang relevan antara persahabatan dengan kecerdasan adversitas, yaitu seseorang akan selalu belajar dari pengalaman ketika berinteraksi dengan orang lain. Persahabatan mengembangkan kemampuan tersebut. Mereka belajar dari orang tua, saudara yang lebih tua, atau orang lain termasuk sahabat yang berhasil mengatasi frustasi dan membuat situasi yang terbaik dari hal buruk. Mereka menghadapi perubahan yang terjadi pada diri mereka, mencari solusi, dan belajar bahwa mereka memiliki keahlian untuk mengendalikan semua hal-hal buruk yang menimpa mereka.

Dacey \& Kenny (1997) juga menambahkan bahwa kemampuan remaja utk beradaptasi dengan baik meskipun dihadapkan pada situasi yang sulit dipengaruhi oleh lingkungan keluarga. Lingkungan keluarga yang selalu memberikan dukungan pada remaja dapat memberikan perasaan hangat pada diri remaja tersebut. Perasaan hangat merupakan salah satu faktor pelindung bagi remaja untuk menghadapi hal-hal beresiko 
dalam kehidupan remaja. Orang tua remaja yang dapat beradaptasi dengan keadaan sulit akan menggabungkan dukungan, pengertian dan pengawasan serta disiplin yang konsisten pada aktivitas anak-anak.

Faktor kedua yang mempengaruhi kemampuan remaja untuk dapat beradaptasi dengan baik meskipun dihadapkan pada situasi sulit adalah jaringan sosial. Masyarakat yang memberikan dukungan penuh pada remaja akan membuat remaja percaya pada kemampuannya dalam mengatasi masalah. Dan faktor ketiga adalah karakteristik kepribadian.

Empati juga berperan dalam kecerdasan adversitas, yaitu kemampuan untuk mengatasi kesulitan yang dihadapi oleh seseorang. Empati adalah Kemampuan berupa respon emosional yang sangat menyerupai respon emosional orang lain (Eisenberg \& Stayer, 1990), namun tidak membuat individu harus benar-benar menyatu dalam emosi, pikiran dan tindakan orang lain; respon emosi yang kongruen namun tidak identik. Empati merupakan konsep multidimensi-onal, dalam ranah afektif dan kognitif (Goldstein dan Michaels, 1985). Konsep tersebut tidak dapat meninggalkan ranah perilaku yang menjadikan empati menjadi nyata. Matangnya kemampuan tersebut membuat seseorang mampu menilai diri sendiri dan orang lain. Sebelum seseorang dapat menempatkan posisi diri pada posisi diri dan orang lain, kemampuan empati sendiri berdasar pada pemahaman diri dalam lingkup hubungan interpersonal.

Empati dibangun berdasarkan kesadaran diri, jika individu semakin terbuka dengan emosinya, keterampilan membaca perasaan semakin meningkat (Goleman, 1998); sehingga individu menjadi lebih dapat menilai diri sendiri, lebih dapat memperhatikan dan menyadari pendapat orang lain mengenai dirinya. Dengan memahami diri dan apa yang dimiliki mahasiswa sebagai pribadi akan memiliki konsep diri yang kuat, sebagai dasar keyakinan terhadap tugas yang berhubungan dengan orang lain. Pada akhirnya kemampuan empati yang berkembang optimal menjadikan mahasiswa tahan terhadap kritik dan masukan dari orang lain dan mampu menempatkan posisi yang tepat dalam menghadapi segala tugasnya.

Hal kedua yang dibahas adalah sumbangan efektif vaariabel empati dan persahabatan sebesar $2,7 \%$ terhadap variabel kecerdasan adversitas. Angka tersebut relatif kecil, karena berdasarkan definisi kecerdasan adversitas adalah suatu kemampuan untuk mengubah hambatan menjadi suatu peluang keberhasilan mencapai tujuan (Stoltz, 2000). Kecerdasan adversitas mempengaruhi pengetahuan, kreativitas, produktivitas, kinerja, usia, motivasi, pengambilan resiko, perbaikan, energi, vitalitas, stamina, kesehatan, dan kesuksesan dalam pekerjaan yang dihadapi.

Faktor internal seperti kemauan, kepribadian, kesehatan, tingkat pendidikan, genetika, keyakinan, dan faktor eksternal (keluarga) tampak dominan. Faktor eksternal ini yang dimungkinkan untuk memunculkan faktor internal, seperti kemauan, keyakinan dan lain-lain. Melalui interaksi dengan orang lain, persahabatan dan pengembangan empati, seseorang dalam hal ini mahasiswa yang sedang skripsi dapat belajar tentang kemauan, kreativitas, motivasi untuk mengembangkan kecerdasan adversitas yang dimiliki, mampu bertahan dan menghadapi tantangan selama mengerjakan skripsi.

\section{KESIMPULAN}

Terdapat hubungan yang signifikan antara empati, persahabatan, dan kecerdasan 
adversitas pada mahasiswa Psikologi Undip yang sedang mengerjakan skripsi. Semakin tinggi empati dan persahabatan yang dimiliki, maka semakin tinggi pula kecerdasan adversitas yang dimiliki oleh mahasiswa Psikologi Undip yang sedang mengerjakan skripsi, dan sebaliknya semakin rendah empati dan persahabatan yang dimiliki, semaakin rendah pula kecerdasan adversitas yang dimiliki oleh mahasiswa Psikologi Undip yang sedang mengerjakan skripsi.

\section{DAFTAR PUSTAKA}

\section{---------. Buku Pedoman Universitas Diponegoro Th. 2004-2005. Semarang: Badan Penerbit Universitas Diponegoro. \\ Buku Panduan Akademik Program Studi Psikologi Fakultas Kedokteran Universitas Diponegoro Th. 1999. Semarang: Program Studi Psikologi Fakultas Kedokteran Universitas Diponegoro.}

Ahmadi, A. (2007). Psikologi sosial. Jakarta: Rineka Cipta.

Baron-Cohen S. \&. Wheelwright S. (2004). The empathy quotient: an investigation of adults with Asperger syndrome or high functioning autism, and normal sex differences: Journal of Autism and Developmental Disorder. 163-175.

Hoffman, M. L. (1984). Interaction of affect and cognition in empathy. Cambridge: Cambridge University Press.

Campbell, S. M., Brehm, S. S., Miller, R. S., Perlman, D. (2002). Intimate friendship. New York : McGraw-Hill.
Chaplin, J.P. (1997). Kamus lengkap psikologi .Penerjemah Kartini Kartono. Jakarta : Raja Grafindo Persada.

Dacey, J. \& Kenny M. (1997). Human development- second edition. United State of America: Times Mirror Higher Education Group Inc.

Dariyo, A. (2003). Psikologi perkembangan dewasa muda. Jakarta: PT Gramedia Widiasarana.

Devito, J. A. (1995). The interpersonal communication book. New York: Harper Collins Collage Publisher

De Vries, B., Adams, Rebecca G., Rosemary, Bliezner. (2000). Definitions of friendship in the third age: Age, gender, and study location effects. Journal of Aging Studies 14.1 (March 2000). Gale : JAI Press, Inc .

Eisenberg, N. \& Strayer, J. (1990). Empathy and its development. Cambridge: University Press.

Goleman, D. (1998). Kecerdasan emosional: Mengapa EI lebih penting daripada IQ. Alih Bahasa : T. Hermaya. Jakarta: Gramedia.

Hurlock, E. B. (1991). Perkembangan anak. Edisi keenam. Jakarta. Erlangga.

Masten, A. S. \& Gewirtz, A. H. (2006). Vulnerability and resilience in early child development. Springer: Blackwell Publishing Ltd.

Monks, F. J., Knoers, A. M. P., \& Haditono, S. R. (2001). Psikologi Perkembangan, Pengantar dalam Berbagai Bagiannya. Yogyakarta: Gadjahmada University Press. 
Moreno, R. (2004, 19 Januari). Diakses dari http://www.republika.co.id/ suplemen/cetak_detail.aspmid=7\&id= 150896 \&kat_id=105\&kat_id1 $=232 \&$ kat_id2=236

Pangestuti, R. (2003). Penundaan menyelesaikan skripsi: Studi kasus pada beberapa mahasiswa angkatan '96 Program Studi Psikologi Fakultas Kedokteran Universitas Diponegoro. Skripsi. Tidak Dipublikasikan. Semarang. Program Studi Psikologi Fakultas Kedokteran UNDIP.

Papalia, D., \& Olds, S. (1998). Human development. (7thed). New York: Mc. Graw Hill.

Papalia, D., Olds, S., \& Feldman, R. (2001). Human development. New York : Mc. Graw Hill.

Poerwadarminta, W. J. S. 1983. Kamus umum Bahasa Indonesia. Jakarta: Balai Pustaka.

Riewanto, A. (2003, 5 Febuari). Skripsi barometer intelektualitas mahasiswa. Suara Merdeka.
Redl, F. \& Watten, W. W. (1990). Mental hygiene and teaching. New York: Harcourt, Brace \& World, Inc.

Santrock. (1995). Life-span development. New York: Mc Graw-Hill Companies, Inc.

Santrock. (2003). Life-span development. New York: Mc Graw-Hill Companies, Inc.

Stoltz. P. G. (2000). Adversity quotient: Mengubah hambatan menjadi peluang. Jakarta: Grasindo.

Stoltz, P. G. (2008). Adversity quotient: Mengubah hambatan menjadi peluang, Jakarta: Grasindo.

Taufik. (2012). Empati pendekatan psikologi sosial. Jakarta: Raja Grafindo Persada. 